\title{
Biotin-labelled antigen screening test for toxoplasma IgM antibody
}

\begin{abstract}
A W L JOSS, L J SKINNER, I L MOIR, J M W CHATTERTON, H WILLIAMS, D O HO-YEN Scottish Toxoplasma Reference Laboratory, Microbiology Laboratory, Raigmore Hospital, Inverness, Scotland
\end{abstract}

SUMMARY A method for the simple preparation of biotin-labelled toxoplasma antigen was used with avidin peroxidase in an IgM-capture enzyme linked immunosorbent assay (BAM-ELISA). Although the overall predictive value of a positive result was only $38 \%$, its low cost and $100 \%$ sensitivity makes it a very suitable screening test. Positive results can be confirmed by an alternative assay, thus providing a more economical and effective diagnostic service than either screening all sera by a commercial test or selecting sera for IgM testing.

Tests for the presence of specific IgM, in conjunction with the Sabin-Feldman dye test ${ }^{1}$ provide the basis of reference laboratory investigation for evidence of current toxoplasmosis. The dye test is labour intensive and specimens are usually screened before submission by haemagglutination, or complement fixation assays, or by enzyme immunoassays. In Scotland the low incidence of toxoplasmosis ${ }^{2}$ makes it difficult to justify two expensive commercial screening immunoassays for IgM and IgG. ${ }^{3}$ Initial screening with an IgM assay would detect cases of acute or current infection but would fail to identify most cases of previous infection, persistent infection, ocular toxoplasmosis, or the late diagnosis of congenital infection. With an IgG screening test, provided the sensitivity is high, virtually all cases are detected as the disease is usually well established before investigations are begun. Nevertheless, to improve detection of early infection it would be more satisfactory to test for specific IgM, and we have developed just such a method in the form of an inexpensive IgM-capture assay to use in conjunction with an IgG screening assay.

\section{Material and methods}

Sera are referred to the Scottish Toxoplasma Reference Laboratory from hospitals throughout Scotland and Northern Ireland, mostly on the basis of a positive IgG-ELISA or haemagglutination screen test. The biotin-avidin capture enzyme linked immunosorbent assay for toxoplasma IgM (BAM-

Accepted for publication 4 August 1988
ELISA) was initially assessed on a panel of sera of known specific IgM results. It was then evaluated as a screening test on 910 sera referred to the laboratory over four months. A panel of sera selected from patients with diseases known to produce false positive results in IgM immunoassays-namely, rheumatoid factor (RF), anti-nuclear antibody, and Paul Bunnell positive and negative sera from patients with glandular fever-like illness-were also tested.

PREPARATION OF BIOTIN-LABELLED

TOXOPLASMA ANTIGEN

Toxoplasma trophozoites (RH strain) from cotton rat peritoneal exudate were washed three times with isotonic saline and resuspended in $0.1 \mathrm{M}$ sodium bicarbonate/saline, $\mathrm{pH} 8 \cdot 5$, at a protein concentration of $10 \mathrm{mg} / \mathrm{ml}$. Biotin (Sigma Chemicals, Poole, Dorset), as N-hydroxy succinimidobiotin (BNHS; $0.25 \mathrm{mg}$ ) or biotinamidocaproate $\mathrm{N}$-hydroxysuccinimide (BNHSC; $0.33 \mathrm{mg}$ ) in $0.3 \mathrm{ml}$ dimethylformamide (BDH, Glasgow), was added slowly to $1 \mathrm{ml}$ of antigen. ${ }^{4}$ After one hour at room temperature the mixture was freeze-thawed twice and centrifuged at $12000 \mathrm{~g}$ for one hour. The pellet was further extracted with $1 \%$ sodium deoxycholate (DOC) in $0.02 \mathrm{M}$ phosphate buffered saline (PBS), pH 7.2, with agitation at $45^{\circ} \mathrm{C}$ for four hours ${ }^{5}$ and clarified at $45000 \mathrm{~g}$ for 20 minutes. Both supernatants were dialysed against four changes of PBS and stored in $50 \%$ glycerol at $-20^{\circ} \mathrm{C}$. DOC extraction was the more reliable method of obtaining a product with suitable activity; likewise, BNHSC-labelling was superior, presumably because the presence of a caproate spacer reduces steric hindrance between the labelled antigen and avidin peroxidase. 
PROCEDURE FOR BAM-ELISA

The ELISA was carried out in polystyrene microtitre plates (Virion B FB; Northumbria Biologicals Ltd (NBL), Cramlington, England) or strips (Lab Systems, Uxbridge) coated overnight at $4^{\circ} \mathrm{C}$ with rabbit IgG to human IgM (1/400) (Dako, Denmark), aspirated, dried at $37^{\circ} \mathrm{C}$ for two to five hours and stored vacuum-sealed at $4^{\circ} \mathrm{C}$. Sera were tested in duplicate at $1 / 100$ in PBS $(100 \mu \mathrm{l})$ containing $0.05 \%$ Tween 20 (PBST) for one hour at $37^{\circ} \mathrm{C}$. After washing four times in PBST a mixture of biotin-labelled antigen at optimum dilution and avidin peroxidase $(4.2 \mu \mathrm{g} / \mathrm{ml}$ ) (Sigma) in $20 \%$ toxoplasma antibody negative human serum in PBST $(100 \mu \mathrm{l})$ was added. After one hour at $37^{\circ} \mathrm{C}$ the wells were washed four times in PBST and $100 \mu \mathrm{l}$ substrate (3,3', 5,5'tetramethyl benzidine (TMB) (Sigma) and hydrogen peroxide in citrate acetate buffer, $\mathrm{pH}$ 6.0) added for 30 minutes at room temperature. The reaction was stopped with $100 \mu 12 \mathrm{M}$ sulphuric acid, and the optical density (OD) at $450 \mathrm{~nm}$ read by plate reader. Samples were judged to be positive or negative relative to a threshold $=$ (mean low positive OD + mean negative OD)/2. Initially the threshold was adjusted to be equivalent to that of the Toxonostika IgM-ELISA, but for screening purposes it was lowered to about the $\mathrm{OD}_{450}$ of the most acute serum available to us, in which the dye test was only $30 \mathrm{IU} / \mathrm{ml}$. To ensure maximum sensitivity, sera were submitted for confirmatory testing when they produced values within $10 \%$ of this threshold. In the evaluation of BAM-ELISA performance sensitivity was measured as (number of BAM
Table 1 BAM-ELISA results in selected sera

\begin{tabular}{|c|c|c|c|c|c|}
\hline \multirow{2}{*}{$\begin{array}{l}\text { Disease } \\
\text { stage }\end{array}$} & \multirow{2}{*}{$\begin{array}{l}\text { No of } \\
\text { sera }\end{array}$} & \multicolumn{2}{|c|}{$B A M-E L I S A$} & \multicolumn{2}{|c|}{ Toxonostika-M } \\
\hline & & + & \pm & + & \pm \\
\hline $\begin{array}{l}\text { Acute } \\
\text { Non-acute* }\end{array}$ & $\begin{array}{l}28 \\
46\end{array}$ & $\begin{array}{r}28 \\
1\end{array}$ & $\begin{array}{l}0 \\
1\end{array}$ & $\begin{array}{r}27 \\
6\end{array}$ & $\begin{array}{l}1 \\
0\end{array}$ \\
\hline
\end{tabular}
equivocal.

true positive/number of expected positive) 100 , specificity as (number of BAM true negative/number of expected negative) 100 , predictive value of a positive result (PVP) as (number of BAM true positive/total BAM positive) 100 and predictive value of a negative result (PVN) as (number of BAM true negative/total BAM negative) 100.

\section{OTHER TESTS}

The DT was carried out as previously described. ${ }^{2}$ The IgG-ELISA screening test was produced in the reference laboratory using Virion $B$ microtitre plates coated with a soluble extract of toxoplasma

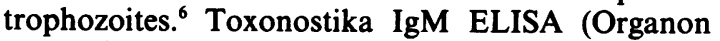
Teknika, Cambridge), our current routine IgM test, was carried out according to the manufacturer's instructions.

\section{Results}

\section{BAM-ELISA PERFORMANCE}

The BAM-ELISA was initially evaluated on a panel of 74 sera, 28 from acute cases, and 46 from patients who

Table 2 BAM-ELISA screening results, analysed according to Toxonostika-IgM confirmatory results and other serological and clinical evidence of infection

\begin{tabular}{|c|c|c|c|c|c|}
\hline \multirow[b]{2}{*}{$\begin{array}{l}\text { Toxonostika-IgM } \\
\text { result }\end{array}$} & \multirow[b]{2}{*}{$\begin{array}{l}\text { Other evidence } \\
\text { of recent infection }\end{array}$} & \multirow[b]{2}{*}{$\begin{array}{l}\text { No of } \\
\text { sera }\end{array}$} & \multicolumn{3}{|c|}{$B A M$ result } \\
\hline & & & + & \pm & $\begin{array}{l}\text { Percentage } \\
+ \text { or } \pm\end{array}$ \\
\hline \multirow[t]{2}{*}{+} & $\begin{array}{l}\text { Good } \\
\text { Insufficient } \\
\text { Improbable }\end{array}$ & $\begin{array}{r}23 \\
9 \\
2\end{array}$ & $\begin{array}{r}23 \\
7 \\
0\end{array}$ & $\begin{array}{l}0 \\
2 \\
0\end{array}$ & $\begin{array}{r}100 \\
100 \\
0\end{array}$ \\
\hline & Total & 34 & 30 & 2 & 94 \\
\hline \multirow[t]{2}{*}{ \pm} & $\begin{array}{l}\text { Good } \\
\text { Insufficient } \\
\text { Improbable }\end{array}$ & $\begin{array}{l}2 \\
2 \\
2\end{array}$ & $\begin{array}{l}1 \\
1 \\
0\end{array}$ & $\begin{array}{l}1 \\
1 \\
0\end{array}$ & $\begin{array}{r}100 \\
100 \\
0\end{array}$ \\
\hline & Total & 6 & 2 & 2 & 67 \\
\hline \multirow[t]{2}{*}{-} & $\begin{array}{l}\text { Good } \\
\text { Insufficient } \\
\text { Improbable } \\
\end{array}$ & $\begin{array}{r}7 \\
11 \\
198 \\
\end{array}$ & $\begin{array}{l}5 \\
5 \\
8 \\
\end{array}$ & $\begin{array}{r}2 \\
6 \\
10 \\
\end{array}$ & - \\
\hline & Total & 216 & 18 & 18 & 17 \\
\hline \multirow[t]{2}{*}{ Total not tested } & & 654 & 8 & 10 & $2 \cdot 7$ \\
\hline & Total & 910 & 58 & 32 & 10 \\
\hline
\end{tabular}

$\pm=$ Positive in only one of duplicates, or within $10 \%$ of threshold. 
were not recently infected. The BAM-ELISA was $100 \%$ sensitive (table 1) and more specific than the Toxonostika test. The BAM-ELISA also detected specific IgM in three out of six sera from confirmed congenitally infected babies, one better than the commercial test. Conversely, uninfected neonatal specimens, tested at $1 / 20$, especially if haemolysed and therefore not recommended for testing by Toxonostika, were less likely to produce false positive results in the BAM-ELISA. Both assays could remain positive for more than a year and, after reactivation, become positive again.

\section{ROUTINE SCREENING BY BAM-ELISA}

Of the 910 referred sera, BAM-ELISA detected specific IgM in all 23 cases with unequivocal evidence of acute or recent infection (table 2). Its overall specificity was $94 \%$ ( 816 negative out of 870 Toxonostika negative or not tested), and included seven cases where the clinical evidence and dye test might have suggested recent toxoplasmosis despite the Toxonostika-IgM result. The overall PVN was $100 \%$, but the PVP was only $38 \%$ (34 Toxonostika positive or "good + /-" out of 90 BAM positive or $+/-$ ).

Despite its poor PVP, its substitution for the present criteria used to select sera for IgM confirmation (dye test of $\geqslant 65 \mathrm{IU}$ or strongly suggestive clinical evidence of infection) would reduce the number of commercial tests from $28 \%$ to $12 \%$ (table 3 ). The effect of lowering the screening threshold was a doubling of the number of screen positive results. Results were also occasionally influenced by the presence of rheumatoid factor, or Paul Bunnell antibody (figure) but the BAMELISA titres were invariably lower than those found in cases of confirmed toxoplasmosis.

\section{Discussion}

Specific IgM tests have until now been used to provide definitive evidence of recent or current toxoplasmosis. The BAM-ELISA was developed to be used in parallel with IgG-ELISA as screening tests on all submitted

Table 3 Relative efficiency of current method compared with BAM-ELISA for selecting sera for routine IgM testing

\begin{tabular}{lll}
\hline & \multicolumn{2}{l}{ No of sera } \\
\cline { 2 - 3 } & $\begin{array}{l}\text { Total } \\
\text { available }\end{array}$ & $\begin{array}{l}\text { Selected } \\
(\%)\end{array}$ \\
\hline $\begin{array}{l}\text { Selected for IgM test-current: } \\
\text { DT } \geqslant 65 \text { IU }\end{array}$ & 910 & $\begin{array}{c}191(21) \\
65(7)\end{array}$ \\
$\begin{array}{l}\text { Clinical reasons } \\
\text { Total }\end{array}$ & & $256(28)$ \\
$\begin{array}{l}\text { Screened + or } \pm \text { by BAM-ELISA } \\
\text { Using Toxonostika-M threshold }\end{array}$ & 628 & $39(6)$ \\
$\begin{array}{l}\text { Using in-house threshold } \\
\text { Within 10\% of in-house threshold }\end{array}$ & 722 & $64(9)$ \\
\hline
\end{tabular}

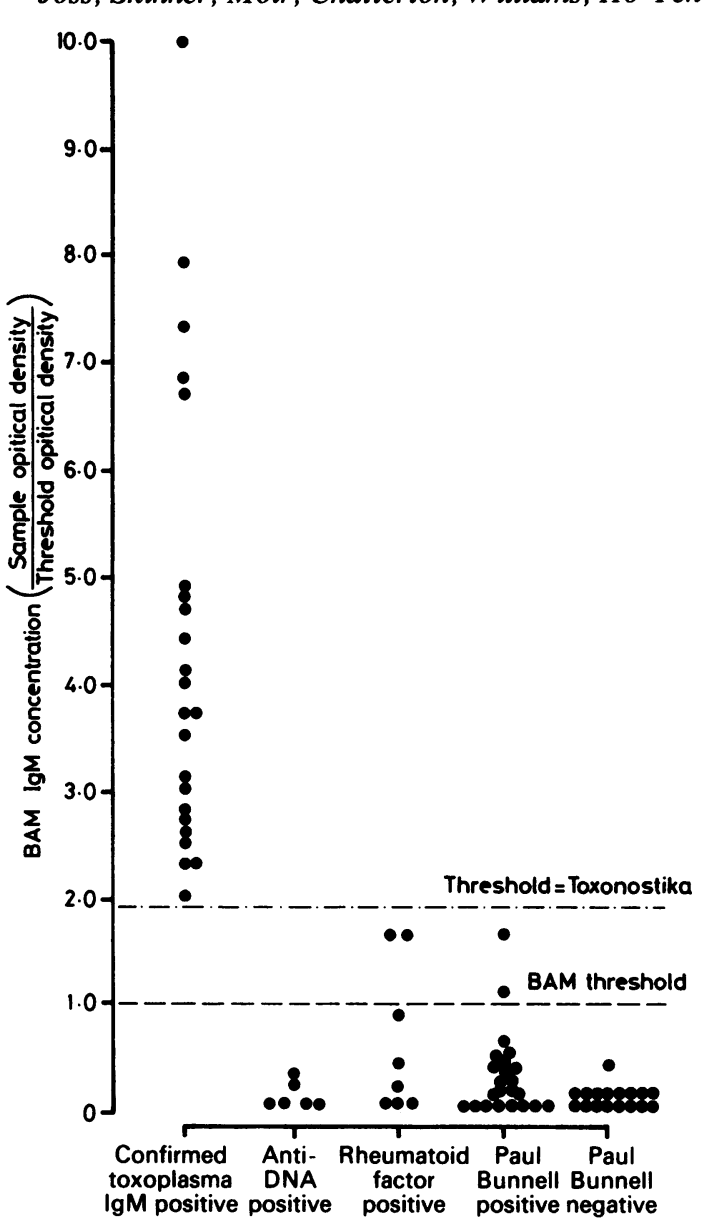

Figure $B A M I g M$ titres in sera from various patient groups.

specimens. Positive IgG screen results require confirmation by dye test and the IgM positive results by an alternative, probably commercial IgM immunoassay. The BAM-ELISA was at least as sensitive as the Toxonostika IgM test, previously found to be more sensitive than IgM-IF. ${ }^{7}$ It was $94 \%$ specific during routine screening. The fairly low $38 \%$ PVP was based on first-run tests and would be improved in a definitive diagnostic situation, when repeat tests for equivocal or discrepant results are standard practice. Toxonostika IgM also produced random false positive results in our hands when used as a screening test (unpublished data).

IgM-capture assays are designed to avoid false positive results caused by rheumatoid factor or antinuclear factor IgM. ${ }^{8}$ If the conjugate consists of unlabelled antigen and labelled anti-toxoplasma antibody, the latter must be $F_{c}$ depleted $^{78}$ or mono- 
clonal.' Alternatively, the antigen itself may be labelled, as in the present study. It is simpler to use biotin than to label directly with peroxidase..$^{10}$ It is difficult to explain why rheumatoid factor and Paul Bunnell positive sera should react in the BAM-ELISA unless they contain a cross-reacting antibody of broad specificity. By raising the threshold by $70 \%$ (or 0.07 OD units), it would be possible, as in similar tests, ${ }^{10}$ to avoid this sort of low false positive reaction. It is preferable, however, to opt for maximum sensitivity at the screening stage and make the definitive diagnosis on the basis of dye test and confirmatory IgM tests.

The biotin reagent is inexpensive to make partly because it makes use of surplus trophozoites produced for the toxoplasma dye test. It is stable at $-20^{\circ} \mathrm{C}$, in $50 \%$ glycerol, for at least one year. Sera could be screened at less than $5 \%$ of the cost by equivalent commercial assays. The number of commercial IgM tests could be reduced by $57 \%$ if they were selected on the basis of BAM-ELISA screen results, giving a $46 \%$ saving for the combined cost a week of screen and confirmatory IgM testing.

The BAM-ELISA can be performed in three hours in parallel with our routine IgG-ELISA screening test from the same master dilutions of patient sera representing a considerable saving of operator time and sample manipulation. Dual screening for toxoplasma IgM and IgG is now possible comparatively cheaply to non-specialised centres. The dye test is likely to remain the definitive serological test for toxoplasmosis in this country, but the high sensitivity of these two ELISA tests would guarantee a sound basis for referral of specimens.

We thank Miss Vivian MacFarquhar for typing the manuscript.
References

1 Sabin AB, Feldman HA. Dyes as microchemical indicators of a new immunity phenomenon affecting a protozoan parasite (Toxoplama). Science 1948;108:660-3.

2 Williams KAB, Scott JM, MacFarlane DE, Williamson JMW, Elias-Jones TF, Williams H. Congenital toxoplasmosis: a prospective survey in the West of Scotland. $J$ Infect 1981;3: 219-29.

3 Balfour AH, Harford JP. Detection of specific IgG and IgM antibodies to Toxoplasma gondii with a commercially available enzyme immunoassay kit system. J Clin Pathol 1985;38:679-89.

4 Adler-Storthz K, Kendall C, Kennedy RC, Henkel RD, Dreesman GR. Biotin-avidin-amplified enzyme immunoassay for detection of herpes simplex virus antigen in clinical specimens. $J$ Clin Microbiol 1983;18:1329-34.

5 Evans RT, Taylor-Robinson D. Development and evaluation of an enzyme linked immunosorbent assay (ELISA), using chlamydial group antigen, to detect antibodies to Chlamydia trachomatis. J Clin Pathol 1982;35:1122-8.

6 Joss AWL, Skinner LJ, Chatterton JMW, Chisholm SM, Williams HD, Ho-Yen DO. Simultaneous serological screening for congenital cytomegalovirus and toxoplasma infection. Public Health 1988;102:409-17.

7 Wielaard F, van Gruijthuijsen H, Duermeyer W, Joss AWL, Skinner L, Williams H, van Elven EH. Diagnosis of acute toxoplasmosis by an enzyme immunoassay for specific immunoglobulin M antibodies. J Clin Microbiol 1983;17:981-7.

8 Naot Y, Barnett EV, Remington JS. Methods for avoiding falsepositive results occuring in immunoglobulin $\mathbf{M}$ enzyme-linked immunosorbent assays due to the presence of both Rheumatoid Factor and antinuclear antibodies. J Clin Microbiol 1981;14: 73-8.

9 Payne RA, Joynson DWM, Balfour AH, et al. Public Health Laboratory Service enzyme-linked immunosorbent assay for detecting toxoplasma specific IgM antibody. J Clin Pathol 1987;40:276-81.

10 van Loon AM, van der Logt JTM, Heessen FWA, van der Veen J. Enzyme-linked immunosorbent assay that uses labelled antigen for detection of immunoglobulin $\mathbf{M}$ and $\mathbf{A}$ antibodies in toxoplasmosis: comparison with indirect immunofluorescence and double-sandwich enzyme-linked immunosorbent assay. $J$ Clin Microbiol 1983;17:997-1004.

Requests for reprints to: Dr A W L Joss, Microbiology Laboratories, Raigmore Hospital, Inverness IV2 3UJ, Scotland. 